\title{
Content Reading and ESL Students
}

Lee Gunderson

Many districts in the United States and Canada have majority ESL populations. ESL students in secondary schools are enrolled in content classes such as Social Studies where the ability to read and comprehend English is vital. Reading is such a vital skill that many states in the United States require secondary teachers to take courses in reading methodology. Farrell and Cirrincione (1984), for instance, found that $63 \%$ of state agencies required all content teachers to have a course in reading methods while $10 \%$ required only teachers of English/language arts to have such a course. Only 14 states did not require a reading methods course for content teachers. It has also been observed that content teachers' attitudes toward teaching reading has improved considerably over the last decade or so (Stieglitz, 1983). However, as Ratekin, Simpson, Alvermann, and Dishner (1985) note "... changing teachers' knowledge and attitudes about content reading strategies does not guarantee they will use those strategies in the classroom" (p. 432). An analysis of observations of eight classes - math, science, social studies, English/language arts - at grades 8 and 11 , led the authors to conclude that content teachers use one textbook with their class rather than a variety, information in the textbooks is the same as that of lectures, and the use of adjunct aids is extremely low. Content area teachers do not incorporate content reading methods into their daily lessons. An important area to be addressed concerns ESL students. Do content teachers modify their instruction relative to the needs of students whose first language is not English? This study was conducted in order to discover more about the nature of ESL reading instruction in content area classrooms.

Procedure. A questionnaire was designed containing 26 items. This paper reports on the responses of secondary content-area teachers who were asked to: 1) "Describe carefully how you instruct ESL students in your classroom," and 2) "How could ESL students be better prepared to meet the requirements of your content classes?"

Subjects. Five hundred subjects were randomly selected by computer from the membership roles of the British Columbia Teachers' Federation (BCTF) and the British Columbia Association of Teachers of English as an Additional Language (TEAL). Each of the approximately 30,000 teachers in the province is required by legislative mandate to belong to BCTF while the TEAL membership consists of individuals who are interested in ESL matters. Questionnaires were mailed to the 500 
teachers, along with a self-addressed stamped envelope for return. Questionnaires returned within a thirty day period were analyzed.

Results. Three hundred twelve $(62 \%)$ questionnaires were returned including responses from: 100 elementary mainstream, 73 secondary mainstream, 26 elementary ESL, 20 secondary ESL, 37 ESL adult, 3 preschool, 12 elementary remedial reading, 9 secondary remedial reading, and 12 community college teachers, 16 administrators, and 4 university professors. An analysis of responses revealed that elementary ESL students are taught, in the majority of cases, to read using a basal reading approach while secondary ESL students are taught to read using an eclectic approach (Gunderson, 1985).

The first content item was: "I will answer the following questions based on," followed by 14 choices ranging from "what occurs in my selfcontained classroom" to "other" followed by a blank. There were no differences in the pattern of responses of teachers between organizations, so questionnaire data were pooled and are reported as a whole. Forty of the content teachers $(54.80 \%)$ responded that "As a secondary teacher I am not involved in reading instruction." However, only 11 (15.0\%) did not respond to further questionnaire items. Sixty-three percent indicated they did not know if ESL students were being taught to read.

There is controversy concerning the appropriate time to begin instruction in English. Some suggest students should not be taught to read until they become proficient in oral English (Sharp, 1973; Ching, 1976) while others suggest they should (Saville \& Troike, 1971). There is also evidence that initial reading instruction should be in "mother tongue" (Modiano, 1968; Mackey, 1972; Lewis, 1965; Yoes, 1967; Kaufman, 1968; Hillerich, 1970; Rosen, 1970; Gutiérrez, 1975; Gamez, 1970). The content teachers were asked: "In your opinion, when should ESL students begin reading instruction?" and "In actuality, how soon do ESL students begin reading instruction after they enter your school?" Sixty-five percent reported that students should begin reading instruction immediately on entering school. Twenty percent thought that instruction should begin after some English while $15 \%$ provided no opinion. Most teachers were not aware of reading programs in their schools. Of the eighteen who responded, all reported that ESL students began reading instruction immediately upon enrollment.

Content teachers do not modify their instruction in response to ESL students' needs and abilities. Only $12 \%$ indicated they restructure classes in response to the needs and abilities of ESL students. Typical comments include: "Generally the only modification is to reword or explain what is needed," "The subject is mathematics so the problem area is "word problems' - generally the only modification is to reword to explain what 
is required," "I think concurrent instruction is best, the ESL teacher can help them with specific assignments," "They do not participate in the theory part of the course and may attain an incomplete grade if their letter grade is a failing one," "give them special English instruction, give them more grammer (sic) and individual help," "I try to give them as much individual attention as possible," and "you do not modify instruction but cover material with more oral and concrete examples rather than relying on abstract concepts."

"How could ESL students be better prepared to meet the requirements of your class?" Over $80 \%(80.80)$ reported that English proficiency should be a requirement of enrollment in content classes. Responses include: "... the ESL teacher could help them learn technical terms that students find more difficult," "give them more individual help in spite of budget cutbacks," "schools should be provided with more ESL staff," "students should be made more aware of English for Special Purposes," "they must be given more outside support by trained ESL teachers in order to manage successfully in a regular academic classroom," "ESL students require stronger reading programs in elementary school in order to allow them to cope with their academic textbook assignments, we should require ESL students to spend more time in an ESL reading program to develop their vocabulary and reading comprehension skills to a more satisfactory level," "be fluent in English before course begins, as a matter of fact this should be a requirement of immigration," "more money for education to help these students survive," "probably retention is the only solution, repetitition of earlier English courses," "combine English composition lessons with technical material required for the shop or laboratory," and "assign an English speaking student to help them in the classroom." Some respondents were simply indifferent about ESL students. One, for instance, reported, "Why do you assume that ESL students need to be prepared to take academic classes, I don't see how they need any more preparation than other students."

Content teachers respond negatively in many cases, e.g., "lack of basic competency in English in an I.A. (industrial arts) shop would be unsafe for students. I refer them to alternate course selections." One cryptic comment concerning ESL students was "I have 8 ESL in one class with 21 others labelled "losers" in a modified course. I can do very little with these fine bright people but work on their English and never mind the course they will fail."

\section{CONTENT READING INSTRUCTION AND ESL STUDENTS}

Undergraduate ESL students indicated overwhelmingly that their grea- 
test need is to learn to read and understand texts and other academic material (Ostler, 1980). Keen (1983), in summarizing ESL research, stated “... instructors must introduce discourse analysis, separate oral skills from reading skills, and instruct students in the various subskills needed to read different types of academic material" (p. 143). It is critically important for teachers to provide content reading instruction for their ESL students. Unfortunately, however, (55\%) in the present study indicated they are not involved in reading instruction. A minority (12\%) reported they restructure their instruction. It is critical that teachers plan for the special needs of ESL students in their content classes.

\section{CONCLUSION}

In the majority of cases ESL students' special needs and abilities are not considered in content classrooms. After observing in both British Columbia and California, I am convinced these findings are not simply representative of isolated classrooms, but secondary classrooms in general. Teachers believe that the problems ESL students represent are beyond their capacity to affect other than to recommend English ability as a prerequisite. However, as Cummins (1981) notes, "Minority-language students, especially Hispanic and Native groups, have been characterized by high drop-out rates and poor academic achievement." $\mathrm{He}$ also indicates that by sixth grade they are two years behind national norms in reading. As a group ESL students are in jeopardy. First, content teachers do not restructure instruction in response to their needs and second, content area reading methods are not incorporated into secondary classrooms. ESL students are left to struggle with both the rigors of academic material and the difficulty of learning to comprehend text in English. It would seem that in many cases they fail at both tasks.

\section{REFERENCES}

Ching, Doris C. (1976). Reading and the Bilingual Child. Newark, Delaware: The International Reading Association.

Cummins, James. (1981). Bilingualism and Minority-Language Children. Toronto, Ontario: The Ontario Institute for Studies in Education.

Farrell, Richard T. and Joseph M. Cirrincione. (1984). State certification requirements in reading for content area teachers. Journal of Reading, 28, 2, 160-164.

Gamez, Gloria I. (1979). Reading in a second language: Native language approach vs. direct method. The Reading Teacher, pp. 665-670.

Gunderson, Lee. (1985). A survey of L2 reading instruction in British Columbia. The Canadian Modern Language Review, 42, 1, pp. 44-55. 
Gutiérrez, Arturo L. (1975). Bilingual education: Reading through two languages. In D.E. Critchlow (Ed.), Reading and the Spanish-Speaking Child. Laredo, Texas: Texas State Council of the International Reading Association, pp. 2-6.

Hillerich, Robert L. (1970). ERMAS: A beginning reading project for Mexican American children. The National Elementary Principal, 50, pp. 80-84.

Kaufman, Maurice. (1968). Will instruction in reading Spanish affect ability in reading English? Journal of Reading, 11, pp. 521-527.

Mackey, William F. Bilingual Education in a Binational School.

Modiano, Nancy. (1968). National or mother tongue language in beginning reading. Research in the Teaching of English, 2, pp. 32-43.

Ratekin, Ned, Michael L. Simpson, Donna E. Alvermann, Ernest K. Dishner. (1985). Why teachers resist content reading instruction. The Journal of Reading, 28,5 , pp. $432-437$.

Rosen, Carl L. (1970). Assessment and relative effects of reading programs for Mexican Americans: A position paper. Albuquerque, New Mexico(ERIC: ED $061000)$.

Saville, Muriel G. and Rudolph C. Troike. A Handbook of Bilingual Education. Washington, D.C.: Teachers of English to Speakers of Other Languages, 1971.

Sharp, D. (1973). Language in Bilingual Communities. London: Edward Arnold.

Stieglitz, Ezra L. (1983). Effects of a content area reading course on teacher attitudes and practices: A four year study. The Journal of Reading, 26, 8, 690-696.

Yoes, Deck, Jr. (1967). Reading programs for Mexican-American children of Texas. The Reading Teacher, 20, 4, 313-18, 323; 14, 4, 481-533.

\section{THE AUTHOR}

Lee Gunderson (Ph.D., University of California, Berkeley) is an assistant professor in the Language Education Department of the University of British Columbia where he teaches undergraduate and graduate courses in reading. Over a period of sixteen years he taught in elementary schools including teaching ESL students, mentally gifted students, and reading disabled students. In addition, he served as principal, vice-principal, ESL reading resource teacher, and reading specialist. His research interests are in first- and secondlanguage reading acquisition. 